DOI: https://doi.org/10.31933/jimt.v2i4 Received: 3 Januari 2021, Revised: 15 Februari 2021, Publish: 13 Maret 2021

JIMT
JURNAL ILMU MANAJEMEN

\title{
FAKTOR-FAKTOR YANG MEMPENGARUHI PERUBAHAN PERILAKU PASIEN KANKER DAN DAYA BELINYA SELAMA MASA PANDEMI TERHADAP OBAT KEMOTERAPI, DAN POLA PROMOSI (SUATU KAJIAN STUDI LITERATUR MANAJEMEN PEMASARAN)
}

\author{
Hartojo Christantyo, E ${ }^{1}$, Wiranata Manggala, I², Febrianto, E , Hapzi Ali ${ }^{4}$ \\ ${ }^{1}$ Mahasiswa Magister Management UMB, email: hartoyo.emmanuel@ gmail.com \\ ${ }^{2}$ Mahasiswa Magister Management UMB, email: istiqlalwm@gmail.com \\ ${ }^{3}$ Mahasiswa Magister Management UMB, email: ekofebrianto27@ gmail.com \\ ${ }^{4}$ Dosen Magister Management UMB, email: hapzi.ali@mercubuana.ac.id
}

\begin{abstract}
Abstrak: Industri farmasi juga salah satu industri yang mengalami dampak dari perubahan perilaku konsumen dan daya belinya terhadap layanan institusi kesehatan selama pandemi Covid-19, dan hal ini mempengaruhi penggunaan Obat Kemoterapi pada masa pandemi saat ini. Cara industri farmasi dalam menghadapi perubahan perilaku konsumen kesehatan dengan aktifitas promosi yang berbeda adalah kunci keberhasilannya dalam menghadapi kondisi pada masa pandemi.
\end{abstract}

Keywords: Perilaku konsumen, daya beli, obat kemoterapi, pola promosi.

PENDAHULUAN

\section{Latar Belakang Masalah.}

Setiap mahasiswa baik Strata 1, Strata 2 dan Strata 3, diwajibkan untuk melakukan suatu penelitian dalam bentuk skripsi, tesis maupun disertasi. Begitu juga bagi dosen, peneliti dan tenaga pengajar juga tenaga funsional lainnya hendaknya aktif melakukan riset dan membuat arktikel ilmiah untuk dipublikasikan pada jurnal-jurnal ilmiah.

Berdasarkan pengalaman empirik banyak mahasiswa, dosen dan para peniliti, kesulitan dalam mencari artikel pendukung dalam riset sebagai bahan penelitian terdahulu atau sebagai penelitian yang relevan yang mana diperlukan untuk memperkuat teori yang ditelitinya, untuk melihat hubungan antar variable dn membangun hipotesis, juga sangat diperlukan pada bagian pembahasan hasil penelitian.

Artikel ini membahas secara khusus faktor Pola Promosi (X2) dari industri farmasi yang berbeda selama masa pandemi dari produk Obat-obatan kanker atau Kemoterapi (X1), yang mempengaruhi Perubahan Perilaku (Y1) konsumennya atau pasien dan Daya Belinya (Y2) selama pengamatan pada masa Pandemi Covid-19 dari bulan April hingga September 2020. Tentu tidak semua faktor yang mempengaruhi Perubahan Perilaku dan Daya Beli pada artikel 
ini dapat disajikan, namun salah satu faktor utama yaitu Pola Promosi dari Industri Farmasi dengan Obat Kemoterapinya akan dikaji pada artikel ini.

\section{Rumusan Masalah.}

Berdasarkan latar belakang masalah diatas akan dirumuskan masalah yang akan dibahas pada artikel literature review ini agar lebih focus pada kajian Pustaka dan hasil serta pambahasannya nanti, yaitu:

1) Apakah penggunaan Obat Kemoterapi memiliki hubungan dan berpengaruh terhadap Perubahan Perilaku Pasien Kanker selama masa Pandemi ini.

2) Apakah penggunaan Obat Kemoterapi memiliki hubungan dan berpengaruh terhadap Daya Beli Pasien Kanker selama masa Pandemi ini

3) Apakah Pola Promosi industri farmasi memiliki hubungan dan berpengaruh terhadap Perubahan Perilaku Pasien Kanker selama masa Pandemi ini.

4) Apakah Pola Promosi industri farmasi memiliki hubungan dan berpengaruh terhadap Daya Beli Pasien Kanker selama masa Pandemi Covid-19.

\section{KAJIAN PUSTAKA}

\section{Perubahan Perilaku Konsumen (Pasien).}

Kebutuhan dan pilihan pembelian seorang konsumen secara khusus akan produk dan merek tertentu dapat digunakan menjadi dasar segmentasi ${ }^{1}$. Ada tiga hal penting yang menjadi dasar dari pemenuhan kebutuhan dan pilihan pembelian, yaitu:

Kebutuhan konsumen, pemahaman alamiah dan tingkat kebutuhan adalah penting dalam menentukan suatu produk memuaskan konsumennya dan menunjukan perubahan pemilihan merek akibat solusi dari kebutuhan konsumen yang lebih baik dan berbeda ${ }^{2}$.

Perilaku pembeli terhadap suatu merek tertentu adalah sangat penting karena menunjukan pengalaman dan pengamatan yang menunjukan kebiasaan yang menjadi perilaku pembelian ${ }^{3}$. Wawasan konsumen, yang mana adalah suatu proses dari pemilihan secara individu, pengaturannya dan mengartikan suatu informasi untuk membentuk suatu gambaran yang berarti bagi konsumen tersebut ${ }^{4}$.

Pelanggan akan berubah pola pembeliannya dikarenakan adanya perubahan dari tahaptahap keputusan pembelian sebagai berikut ${ }^{2}$ :

1. Pengenalan masalah atau kebutuhan

2. Pencarian informasi

3. Menilai berbagai pilihan

4. Keputusan pembelian

5. Perilaku pembelian

Keputusan dan perilaku pembelian dari konsumen atau pelanggan akan berubah seiring dengan adanya pengenalan akan permasalahan yang baru, seperti keadaan Pandemi Covid-19 saat ini.

Terdapat dua hal utama yang menjadi perhatian serius bagi semua masyarakat saat Pandemi Covid-19 tahun 2020 ini, yaitu Kesehatan dan Ekonomi ${ }^{5}$. Hal ini menegaskan bahwa kepedulian terhadap Kesehatan baik perorangan maupun komunitas semakin manjadi prioritas. Bersamaan dengan hal tersebut, terdapat juga kekuatiran terhadap kondisi ekonomi dengan menurunnya permintaan barang dan jasa dikarenakan masyarakat menahan diri terhadap interaksi sosial termasuk interaksi jual-beli. Menurut Accenture, Pandemi ini menciptakan lima 
jenis pelanggan baru yang ditemukan dari para responden yang bersedia terlibat dalam survey tersebut, mereka adalah sebagai berikut:

The Worrier, ditemukan sebanyak $21 \%$, kelompok ini adalah masyarakat usia senior, atau diatas 56 tahun yang menurut mereka sangat rentan kesehatannya selama Pandemi ini.

The Individualist, sebanyak $22 \%$ dan mereka adalah kaum milenial atau keluarga muda berusia antara 18-24 tahun yang lebih peduli kepada panic buying dari pada ancaman kesehatannya.

The Rationalist, sebanyak 40\% yang mana mereka berumur antara 25-31 tahun dan mereka sangat peduli dengan kesehatan diri sendiri dan berharap orang lain juga melakukan hal yang sama.

The Activist, ada sebanyak $8 \%$ dan berumur sama dengan The Rationalist, namun mereka sangat peduli dengan kesehatan masyarakat sekitar dan sangat aktif dalam tanggung jawab sosial The Indifferent, sekitar 10\% dari responden dan mereka ini tidak peduli dengan keadaan sekitar dan menjalankan aktifitas nya berdasar pemahaman mereka sendiri.

Kelompok-kelompok diatas menjadi key driver penggerak ekonomi saat Pandemi tahun 2020 ini dengan tingkat pemenuhan kebutuhan akan berbagai produk dan jasa kesehatan yang tinggi dengan jenis yang berbeda-beda, termasuk penggunaan Obat Anti Kemoterapi dan halhal pendukung lainnya.

Dalam riset Accenture terhadap perilaku konsumen selama Pandemi 2020 ini adalah adanya dominasi kelompok The Worrier dan The Rationalist yang menjadi penggerak Penjualan Obat Anti Kanker seiring dengan penjualan obat-obatan lainnya selama masa Pandemi ini, dan ini bukan persentase yang kecil, total dari kedua kelompok ini sudah memberikan kontribusi lebih dari 60\%. Namun dari kedua kelompok inilah, terjadi perpindahan konsentrasi pembelanjaan harian mereka dari pembelian berdasar keinginan menjadi pembelian berdasarkan kebutuhan dan tentunya kebutuhan kesehatan adalah yang terutama menjadi gaya hidup berbelanja mereka ${ }^{5}$.

Dr David Pinato, dari departemen bedah dan kanker di Imperial College London dan pemimpin studi, mengatakan ia "khawatir" terhadap hasil studi dan meminta Inggris untuk "mengakui tingkat kematian." Perawatan seperti kemoterapi dan imunoterapi sepertinya tidak meningkatkan resiko kematian pasien karena Covid-19, ujarnya. "Ini berarti, dalam banyak kasus, perawatan kanker mungkin aman dilakukan selama pandemi, tergantung pada situasi individiual pasien dan faktor-faktor resiko mereka. Dalam study tersebut didapatkan data diantara 204 pasien yang diamati, 53\% pasien menjalani terapi, dan 45\% tidak mengikutinya, dan $80 \%$ pasien terjangkit virus corona dari lingkungan mereka dan hanya $15 \%$ ditemukan tingkat kematian dalam studi ini. Hal ini menunjukan bahwa pasien kanker payudara dengan mengikuti prosedur yang diberikan, akan mendapatkan perawatan dan terhindar dari kematian akibat Covid-19 14 .

\section{Daya Beli Pasien.}

Ukuran produk atau layanan dan tingkat pemakaian dan pembeliannya merupakan faktor konsumsi dari pelanggan yang merupakan indikasi dari sebagian konsumen dan pasar bisnis yang bisa dikembangkan. Tenaga pemasaran sering menggolongkan pelanggan dan calon pelanggan dalam golongan berdasar besaran pembeliannya. Pengembangan sistem Manajemen Hubungan Pelanggan (CRM, Customer Relation Management) dan program kesetiaan pelanggan, Loyalty Programs, memberikan wawasan perilaku pelanggan dan penggolongannya 
serta menyediakan data yang tepat akan kebutuhan pelanggan dalam berbagai golongan pembeliannya $^{2}$.

Menurut hasil studi dari ASEAN Cost in Oncology (ACTION) pada tahun 2012 di ASEAN, tercatat $13 \%$ pasien kanker mengalami kematian dan $70 \%$ nya berasal dari negara dengan pendapatan rendah dan menengah (WHO, 2010). Dan hal ini menimbulkan beban keuangan tambahan sebesar 30\% yang sangat memberatkan dalam jangka waktu 12 bulan setelah diagnosis kanker. Harga obat kanker yang tinggi, terapi lanjutan yang mahal dan belum semua ditanggung asuransi sehingga kebanyakan pasien datang sudah stadium lanjut. Metode WHO-HAI digunakan untuk mengukur harga obat, ketersediaan dan daya beli pasien selama jangka waktu tertentu ${ }^{11}$.

Pengolahan data lanjutan dilakukan oleh Nur Faizah (2017) dengan menghitung rasio harga obat kanker di RSUD Al Ihsan dibagi harga dari WHO-HAI yang dikonversi ke Rupiah. Hasil yang diperoleh adalah $80 \%$ Originator Brand dan 62\% Lowest Price Generics yang melebihi persyaratan yang ditetapkan oleh WHO-HAI yaitu tidak lebih dari 35\% kenaikan harga obat dari daftar harga obat WHO. Ketersediaan obat kanker di RSUD Al Ihsan tidak mencapai standar metode WHO-HAI, yaitu 50\% obat tersedia di setiap fasilitas kesehatan yang diteliti. Keterjangkauan obat kanker di RSUD Al Ihsan adalah tinggi yaitu 86\% Originator Brand dan 53\% Lowest Price Generics yang membutuhkan lebih dari satu hari bekerja untuk mendapatkan pengobatan. Kesimpulannya, kebanyakan harga obat kanker di RSUD Al Ihsan adalah lebih dari persyaratan yang ditetapkan oleh WHO-HAI sebanyak 35\% kenaikan, sehingga terjadinya kendala pada akses obat kanker yaitu ketersediaan obat tidak mencapai standar WHO dan harga obat kanker yang tidak terjangkau. Oleh karena itu, revisi harga yang sangat dibutuhkan untuk pengembangan kebijakan dan strategi untuk meningkatkan akses pengobatan kanker ${ }^{12}$.

\section{Obat Kemoterapi.}

Pada kondisi Pandemi Covid-19, rumah sakit dan pelayanan medis akan terfokus untuk mengatasi infeksi tersebut. Hal ini menjadi suatu ancaman yang berpotensi pada pasien dengan gangguan sistem imun. Hal tersebut dapat menjadi pertimbangan bahwa terapi pada pasien tersebut akan membawa dampak yang menguntungkan atau merugikan pada kondisi wabah ${ }^{6}$. Saat ini rumah sakit juga melakukan pembatasan kunjungan pasien poliklinik dan pasien rawat inap untuk mengurangi transmisi infeksi COVID-197

Penyakit akibat kanker yang merupakan penyakit kronis yang membutuhkan pengobatan, baik operasi, kemoterapi, radioterapi, imunoterapi, dan terapi target. Hal tersebut berkaitan dengan progresivitas penyakit, kekambuhan, dan pemberantasan penyakit kanker. Apabila terapi pasien kanker, terutama stadium lanjut yang tertunda atau tidak diberikan rutin, maka akan memperburuk kondisi kanker ${ }^{8}$.

Menurut I Nyoman Gede Budiana (2017) kemoterapi pada pasien kanker payudara memainkan peranan penting dalam tatalaksana pasien kanker payudara dan secara umum memiliki jendela terapi yang lebih sempit dari obat-obatan lainnya sehingga pemberian obat kemoterapi akan meningkatkan potensi terjadinya efek samping kerusakan sel normal termasuk Neutropil. Dan kemoterapi adalah penyebab utama Neutropeni pada 90\% kasus kanker. Dan Demam Neutropeni masih merupakan komplikasi efek samping yang paling ditakuti dari penggunaan Obat Kemoterapi Kanker Payudara? 
Berdasarkan hasil studi Liang, dkk, strategi penanganan pasien kanker pada wabah COVID-19 adalah dengan menunda kemoterapi adjuvan atau operasi elektif pada kanker yang stabil. Selain itu perlu adanya perlindungan diri yang baik tiap pasien kanker dan penanganan intensif pada pasien COVID-19 dengan penyakit komorbid atau usia tua ${ }^{10}$. Selain itu, obat antikanker yang diberikan secara intravena dapat diganti dengan obat oral apabila sediaan obat ada, seperti etoposide dan vinorelbine. Pada pasien kanker dengan kemoterapi yang memerlukan obat intravena, dapat ditunda apabila kondisi pasien tidak baik ${ }^{7}$.

Menurut studi Globocan (2018), Kanker Payudara menempati urutan pertama dalam kasus kanker yang dilaporkan di Indonesia dengan angka 58.256 kasus baru pada tahun 2018. Serta, menempati urutan kedua setelah kanker paru-paru sebagai penyebab kematian akibat kanker dengan jumlah mencapai 22.692 kasus di tahun itu. Di seluruh dunia, adalah kanker payudara adalah kanker invansif yang paling umum pada wanita, lebih dari 2 juta wanita terkena dampak penyakit ini setiap tahunnya. Kondisi pandemi ini membuat ruang gerak dan akses terbatas untuk seluruh elemen masyarakat, termasuk bagi pasien kanker payudara, yang harus terus menjalani kemoterapi agar dapat bertahan dari serangan pennyakitnya ${ }^{13}$.

\section{Pola Aktifitas Promosi.}

Masih menurut Accenture (2020) ada perubahan pola kebiasaan berbelanja yang tidak seperti keadaan biasa. Konsumen menerima kebiasaan baru dan gaya hidup ini akan berlanjut dalam jangka waktu yang lama. Ada tiga hal yang menjadi pola baru dari konsumen, sebagai berikut:

- Meningkatnya Gaya Hidup Sehat. Dengan menggunakan Strategi Pemasaran Gaya Hidup Sehat, maka Perusahaan Farmasi akan lebih mendapatkan keuntungan

- Kesadaran akan Belanja Bijak, konsumen mulai menghemat biaya belanjanya dan tidak membuat sampah makanan dan berbelanja seperlunya. Perusahaan Farmasi harus merubah model pemasarannya untuk bisa menjangkau konsumen dengan pola baru ini

- Penggunaan Barang Lokal, kepedulian akan produksi local dan berkembangnya komunitas lokal, akan mendorong Pemasaran Komunitas. Perusahaan Farmasi harus memanfaatkan momentum ini untuk menhembangkan Brand Loyalty di dalam komunitas pengguna 5 .

Masih menurut Accenture, kecenderungan belanja daring akan terus berlanjut dan meningkat seiring dengan masa Pandemi yang belum bisa diperkirakan berakhirnya. Perusahaan Farmasi harus memanfaatkan Promosi Daring baik melalui platform e-commerce maupun media komunikasi daring seperti Zoom, Google Meet, Microsoft Teams dan lainnya untuk menjangkau pribadi konsumen secara virtual. Meningkatkan penggunaan komunikasi digital ini akan meningkatkan pula share of voice produk atau jasa dari Perusahaan Farmasi. Dari hasil survey ini pula, didapatkan data bahwa sebanyak 30\% konsumen menginginkan terus bekerja dari rumah atau Work from Home (WFH) dan sebanyak 46\% konsumen yang belum menjalankan WFH, menginginkan bekerja secara WFH dimasa mendatang. Hal ini membuka cakrawala Perusahaan Farmasi untuk merubah pola promosinya menjadi promosi virtual atau daring 5 .

Bertepatan dengan kondisi Pandemi saat ini, Yayasan Kanker Indonesia bekerja sama dengan Halodoc, sebuah platform layanan kesehatan online, meluncurkan solusi inovatif untuk pasien kanker payudara yang bernama: ASA-DARA. Layanan ini memungkinkan pasien kanker payudara mendapatkan akses terapi yang dibutuhkan, konsultasi dengan dokter ahli kanker dan juga mendapatkan resep terapi kanker payudara serta mendapatkan keringanan biaya obat 
dengan cara yang nyaman dan mudah di seluruh wilayah Indonesia (Kompas.com, 2020). Hal yang dilakukan oleh PT Pfizer Indonesia tersebut telah membuktikan pola promosi persahaan farmasi untuk menghadapi perubahan perilaku konsumen di masa Pandemi Covid-19 ini ${ }^{15}$.

\section{Conceptual Framework.}

Berdasarkan kajian teori dan review ilmiah, maka Conceptual Framework literature review ini adalah seperti dibawah ini:

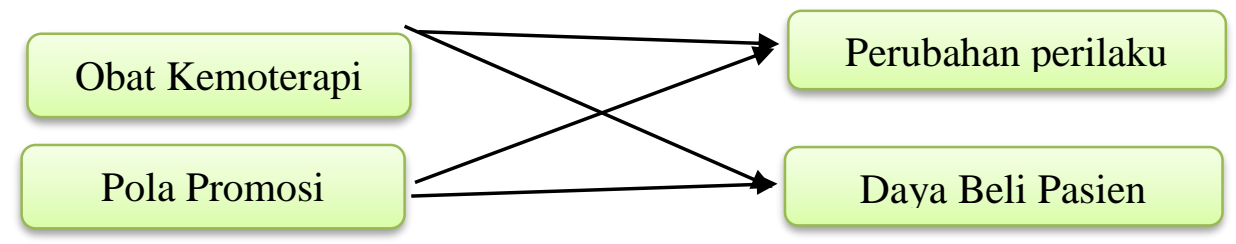

\section{METODE PENULISAN ARTIKEL}

Metode penulisan artikel ilmiah ini adalah dengan metode kualitatif dan studi literature dengan mengkaji buku-buku literature sesuai teori serta menganalisa artikel ilmiah yang memiliki reputasi dan dapat menjadi sumber referensi selanjutnya.

\section{HASIL DAN PEMBAHASAN}

\section{Obat Kemoterapi dan Perubahan Perilaku Konsumen.}

Suatu kebutuhan yang harus dihadapi pasien kanker untuk mendapatkan kemoterapinya di masa Pandemi ini, dan mengharuskan pasien merubah cara mendapatkan terapinya dengan TELEMEDICINE atau pendekatan pengobatan atau terapi melalui daring atau virtual untuk keberlanjutan terapi mereka.

\section{Obat Kemoterapi dan Daya Beli Pasien.}

Daya beli pasien kanker yang menurun akibat Pandemi Covid-19 akan menambah beban mereka, sehingga untuk keberlanjutan terapi mereka, pilihan terapi oral akan lebih mambantu, karena mengurangi biaya rumah-sakit dan biaya perjalanan dari dan ke rumah-sakit, erta biayabiaya lainnya yang bisa dikurangi.

\section{Pola Promosi dan Perubahan Perilaku Konsumen}

Dalam menyikapi perubahan perilaku pasien kanker untuk mendapatkan terapinya, maka industri farmasi harus merubah pola pendekatan atau promosinya dengan cara daring atau virtual dan dalam kemasan yang lebih emphatic dan solutif, karena pasien ingin mendapatkan akses terapinya namun akses terhadap obat kemoterapi akan makin jauh apabila industri farmasi tidak mendekatkan diri dalam cara-cara yang berbeda

\section{Pola Promosi dan Daya Beli Pasien}

Selain dikembangkan akses yang solutif dan emphatic melalui platform daring atau virtual telemedicine, industri farmasi juga harus memberikan harga terapinya yang lebih terjangkau dengan memotong jalur pengadaaan, memberikan compassionate program agar terapi lebih terjangkau dan biaya konsultasi lanjutan dengan telemedicine. Hal ini sangat membantu terutama bagi pasien dalam lanjutan terapi. 


\section{KESIMPULAN DAN SARAN \\ Kesimpulan}

Berdasarkan rumusan artikel, hasil pembahasan yang telah dikaji dan dibahas pada article ini, maka dapat disimpulkan untuk membangun hipotesis guna riset selanjutnya adalah sebagai berikut:

1) Penggunaan atau kebutuhan obat kemoterapi memiliki hubungan dan berpengaruh terhadap Perubahan Perilaku pasien kanker selama masa Pandemi ini.

2) Kebutuhan Obat Kemoterapi juga memiliki hubungan dan berpengaruh terhadap Daya Beli pasien kanker pada masa Pandemi saat ini.

3) Pola Aktifitas Promosi dari industri farmasi memiliki hubungan dan berpengaruh terhadap Daya Beli pasien kanker selama masa Pandemi ini.

4) Pola Aktifitas Promosi dari industri farmasi memiliki hubungan dan berpengaruh terhadap Perubahan Perilaku konsumen atau pasien yang membutuhkan kemoterapi

\section{Saran}

Berdasarkan kesimpulan diatas, maka saran dari artikel ini baik secara akademik maupun empiric adalah sebagai berikut:

Pasien mengharuskan diri mereka untuk berubah perilaku pembelanjaannya terhadap kebutuhan akan terapi kanker menghadapi kondisi Pandemi saat ini dan kebutuhan ini tidak bisa ditunda atu dihilangkan, sedangkan layanan platform kesehatan digital yang direkomendasikan oleh sebuah Yayasan atau institusi yang berkompeten akan dipercaya oleh pasien, hal ini membuka peluang bagi perusahaan farmasi untuk memanfaatkan kesempatan ini sebagai golden time untuk meningkatkan penjualan produk atau jasa mereka dengan juga menambahkan suatu program supaya terapi dapat dijangkau oleh pasien kenker yang membutuhkan akses kemoterapi

\section{DAFTAR PUSTAKA}

1. Meg Carter, Big Business Pitches Itself on Fair Trade Territory, Financial Times, Oct 25, 2005, 13

2. Craven, D.W., Piercy, N.F., (2013). Strategic Marketing, $10^{\text {th }}$ Edition, New York, McGraw-Hill; 82, 47, 84.

3. Henry Assael, Consumer Behavior and Marketing Action, $2^{\text {nd }}$ ed., Boston: PWS-Kent Publishing, 1984, 225.

4. Bernard Berelson and Gary A. Steiner, Human Behavior: An Inventory of Scientific Findings; New York: Harcourt Brace Jovanovic, 1964, 88.

5. Accenture COVID-19 Consumer Research conducted April 2-6, 2020.

6. Ueda M, Martins R, Hendrie PC, et.al. Managing Cancer Care During the COVID-19 Pandemic: Agility and Collaboration Toward a Common Goal. J Natl Compr. Canc. Netw. 2020; 18:1-4.

7. Wang Z, Wang J, He J. Active and Effective Measures for the Care of Patients with Cancer During the COVID-19 Spread in China. JAMA Oncol. 2020: E1-2.

8. Hendry Irawan*, I Wayan Sudarsa, Penanganan Pasien Kanker dan Risiko Infeksi selama Wabah COVID-19; JBN (Jurnal Bedah Nasional); Vol. 4, N0. 1, 2020

9. Budiana, I.N.G., Febiani, M., (2017). Indonesian Journal of Cancer Vol. 11, No. 2 April - June. 
10. Liang W, Guan W, Chen R, et.al., Cancer patients in SARS-CoV-2 infection: a nationwide analysis in China. Lancet Oncol. 2020; 21:335-7.

11. Merel Kimman, Stephen Jan, et.al., Socioeconomic Impact of Cancer in Member Countries of the Association of Southeast Asian Nations (ASEAN); Asian Pacific J Cancer Prev, 2012, vol. 13, 421-425

12. Nur Faizah Binti Hamir, Analisis Harga Obat, Ketersediaan Dan Daya Beli Pasien Pada Terapi Kanker Di Rumah Sakit Umum Daerah Al Ihsan, Provinsi Jawa Barat. Unpad Repository, 2017.

13. Globocan 2018, Graph production: Global Cancer Observatory (http://gco.iarc.fr)

14. DJ Pinato, AJX Lee, F Biello, E Seguí, et al., (2020). Presenting features and early mortality from SARS-CoV-2 infection in cancer patients during the initial stage of the COVID-19 pandemic in Europe- Cancers

15. Masih Pandemi Corona, Pasien Kanker Payudara Bisa Akses Terapi Pakai Digital, Kompas.com - 22/05/2020 